\title{
SUSTAINABLE CONSERVATION FOR HISTORICAL BUILDINGS IN MEDITERRANEAN CITIES
}

\author{
A. AFIFY \\ Department of Architecture, Faculty of Architectural Engineering, Beirut Arab University
}

\begin{abstract}
Nowadays, due to the rapidly changing patterns of life and scale of activities, a more familiar approach towards conservation must be adopted, especially if all the values of historic buildings and towns are to be recognized, preserved and used. Adaptive reuse has proven to be an important strategy in conserving historical buildings. In the literature review of the caravanserais types of historical building, few cases were successfully reused. The focus of this research is the viability of adaptive reuse as a sustainable strategy in the conservation of caravanserais. As they are considered as heritage buildings, the conservation of their cultural significant value is an important goal to achieve. However, this research aims to review the sustainable adaptive reuse of caravanserais and to find a framework of sustainable adaptive reuse for the case studies. As criteria of selection, the selected buildings share several characteristics such as historical values, structural importance and whether they have achieved a successful adaptive reuse process. The criteria of analysis for the selected examples are on two levels: first are the new functional advantages - economically and socially; the second will be conservation status - structure deviation and improvement including discussion on if new materials were used. In addition, from this research we can conclude that adaptive reuse enhances the longer-term usefulness of a building and is therefore a more sustainable option than demolition and rebuilding. The benefits from adaptive reuse include social values and community expectations, economic viability and environmental sustainability. Keywords: adaptive reuse, conservation, historical buildings, Mediterranean cities, sustainable development.
\end{abstract}

\section{INTRODUCTION}

Conservation of the historical buildings plays an important role in the sustainable development of old cities. Adaptive reuse is one of the possible choices to activate the collaboration of an obsolete heritage building in the socio-economic life of the community. This research answers the question of how adaptive reuse of historic buildings generates added or less social and economic values to old city. In other words, reusing existing buildings is a simple way of achieving sustainability [1]. The focus of the study is the caravanserais that have a significant historical value and are situated in a historic context.

\subsection{Sustainable conservation}

According to Rodwell sustainability has three components - environmental, social and economic - of which the environmental takes precedence as it underscores the survival of all life forms on our planet. Historic cities start with two essential qualities: first, the environmental capital that is represented by their buildings and urban infrastructure; and second, the socio-cultural values and what they signify and the role that they perform in defining a sense of place, community belonging and social cohesion. A continuous time line represents these socio-cultural values: past, present and future. They are expressed in the architecture, the urban grain and the socio-economic organization of cities. The physical and societal attributes of historic cities are inseparable. They embrace environmental issues, tangible and intangible cultural heritage, and equity both within and between generations. Recognizing and acting upon the full range of values inherent in historic 
cities is a core component of the challenge [2]. The discussions about building adaptation are characterized broadly under these headings: social, economic and environmental. In addition, there are factors that are regulatory and legal, locational, and physical, which affect adaptation and demand the idea of sustainability be seated within these factors to varying degrees [3].

\subsection{Adaptive reuse}

According to the International Council on Monuments and Sites (ICOMOS), Australia, listed in Burra Charter 1979 and later revised, adaptive reuse means modifying a place to suit the existing use or a proposed use. The adaptive reuse/adaptation of historical building is acceptable only where the adaptation has minimal impact on the cultural significance of the place, and it should involve minimal change to significant fabric, achieved only after considering alternatives. Always, according to Burra Charter, adaptation may involve the introduction of new services, or a new use, or change to safeguard the place.

Douglas defines adaptation as 'to include any work to a building over and above maintenance to change its capacity, function or performance (i.e. any intervention to adjust, reuse or upgrade a building to suit new conditions or requirements)'. Fitch (1990) defines the adaptive reuse as 'the only economic way in which old buildings can be saved, by adapting them to the requirements of new tenants,' where the internal reorganization of space could involve several interventions [4]. As Fig. 1 shows, the adaptive reuse could involve many level of intervention from preservation to rehabilitation and restoration [5].

1. Maintenance: Basic adaptation works including fabric repairs

2. Stabilization: Strengthening and major improvement works to the structure including inserting epoxy resin stitches in wall junctions

3. Consolidation: Medium adaptation and maintenance works including damp proofing measures and timber treatment

4. NReconstruction: Substantial rebuilding of part or parts of the building

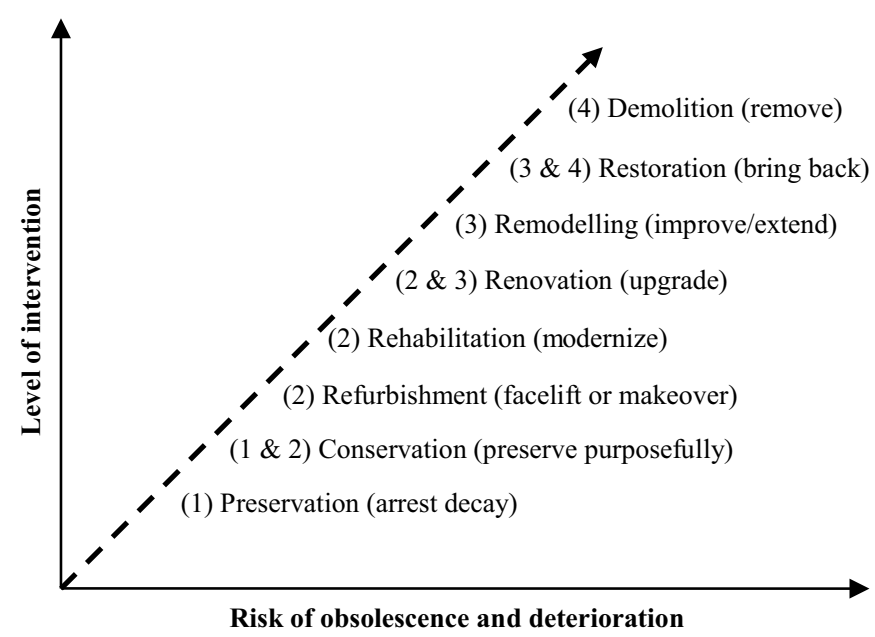

Figure 1: Range of interventions [5]. 
From a physical point of view on adaptation, when a building has been vacant or underutilized for a considerable period of time, six basic options are available: market, leave vacantly, refurbish, modify use, change class of use and demolish. Clearly, there are three dominant possibilities: adaptations for same use plus ancillary uses, adaptations for mixed classes of use and adaptations to a very new class of use [6]. Therefore, adaptive reuse of heritage buildings includes many characteristics as follows:

- Developing the potential of additional use

- Targeting obsolete buildings

- Involving historic preservation, restoration and rehabilitation (through repair, alterations and additions while preserving those portions or features, which convey its historical, cultural or architectural values)

- Finding new use to increase building lifetime

According to Ijla and Broström, historic buildings can be adapted to be reused for different purposes based on factors that include building size and orientation, location, accessibility of surroundings, structural system, outdoor spaces and morphology [7].

\section{HISTORICAL BACKGROUND OF CARAVANSERAI (KHAN/HAN)}

'Khan' originates from a Persian word, meaning 'house'. It was frequently used in inscriptions in Egypt, Syria, Asia Minor and Mesopotamia during the 13th and 14th centuries [8]. The khan served as an inn for travelling merchants, built around a courtyard, with stables and warehouses at ground floor and living accommodations above, and was usually owned by wealthy or powerful people [9]. Based on Petersen's (1996) definitions of khan, many characteristics are revealed:

- A khan is a building that combines the function of a hostel and a trading centre. Standard features, which one might expect to find in a khan, are stables, storerooms, sleeping accommodation and a mosque.

- The earliest Islamic khans are found in Syria and date from the Umayyad period; examples include Qasr al-Hayr East and West, Khan al-Zabib and the building at Tell al-Sadiyyeh in the Jordan valley. These buildings all have a standard plan comprising a square or rectangular enclosure with rooms built around a central courtyard.

- During the Abbasid period, khans were established on the Darb Zubayda, although the commercial importance of these installations is not known.

- From the 12th century onwards, khans became a standard feature of Islamic architecture and were particularly popular among the Seljuk Turks. During this period, khans began to be established in towns where they would become centres for trade.

- During the 16th century, Ottoman khans developed a variety of forms where the central courtyard is enclosed; some of the best examples are in Damascus and Aleppo. Also at this time khan became part of larger complexes that included a mosque, fort and bathhouse [10].

The origin and progress of caravanserais is reciprocal with those of the souk or bazaar. Both were derived from the economic model based on agriculture and trade, which required their development along what is known as the Silk Road, the commercial route connecting China to Rome [8]. In the late Ottoman period, caravanserais attained the additional function of wholesale centres in addition to their original function as hostels and became an integral part of urban design [11]. 


\subsection{Typology of khans}

Unlike khans, caravanserais contained provision for animals, and business was conducted within them. However, they were architecturally similar. They are basically composed of an open courtyard surrounded by a two-storey building that contains the lodging rooms [8]. There are different types of caravanserais in terms of architectural geometry; this variety depends on functional constraints where there are two types of khans: urban and suburban.

- The suburban caravansaries are located along the road for accommodation of passengers.

- The urban caravansaries are located beside markets that are used for trading affairs.

According to Williams, khans were typically rectangular structures built around a patio or courtyard that provided lower-level space for commercial transactions and upper-level accommodations, and were regularly connected to the main street through a corridor [9]. Each corridor or peripheral street was separated from the main path by a gate or door. Closing these doors after sunset guaranteed the security of each khan. A foyer and stairs connected the upper and lower storeys. In some cases, shops were joined to the courtyard through a veranda, or iwan, while a slight height difference between the shops and the courtyard existed [8].

- The urban khan was a warehouse, typically associated with a Waqf. Depending on the ownership and purpose of the khan, it could be free as a service to travelling merchants or it might charge a fee to generate income for the owner or the Waqf [12].

- Caravanserais outside cities were usually one-storey buildings, while those inside cities could be one- or two-storey buildings. They had a simple plan: a rectangle including a central courtyard surrounded by rooms and stables. They cannot be compared to other sorts of caravanserais outside the cities that served as guesthouses for travellers. Sometimes, regular residences served as khans. For instance, some merchants' houses in Mocha (Yemen) were also used as places for commercial negotiations, hostels for their international merchant guests or meeting points for transactions [13].

According to Gharipour, the growing number of tourists visiting bazaars, particularly after the 1970s, converted khans to souvenir bazaars. The idea of the bazaar also changed intensely. Associations slowly morphed into unions rather than concentrated economic entities. In some societies, the bazaar was source of resistance in contradiction to modernism. Modern governments have endeavoured to weaken this effect by modernizing shopping centres [8].

\section{EXAMPLES OF SUCCESSFUL KHANS' ADAPTIVE REUSE PROJECTS}

The three cases taken as models in this research are the following:

- Rüstem Pasa Caravanserai, Edirne, Turkey

- Khan Al-Wakalah, Nablus, Palestine

- Shah Abbas Hotel (Madarshah Caravanserai), Isfahan, Iran

As criteria of selection, the four selected buildings share several characteristics as follows:

- Historicity: they are monumental in their appearance, and they are listed monuments.

- Structural importance: the buildings have structural, solid outer walls and considerable size.

- Original function.

- Having achieved a successful adaptive reuse process. 
The criteria of analysis for the examples are on two levels as follows:

- New functional advantages: economically and socially

- Conservation status: structure deviation and improvement including discussion if new materials were used

While sustainability in building adaptation is defined as a set of processes aimed to deliver efficient built assets in the long term, the examples are analysed through the examination of a set of values, as indicated in Fig. 2, on two levels: the functionality of the building and the conservation status (structure deviation and improvement).

3.1 Rüstem Pasa Caravanserai, Edirne, Turkey - Recipient of the Aga Khan Award for Architecture in 1980

\subsubsection{Brief description}

The caravanserai (once a warehouse and overnight stop for camel caravans) is located in the historical centre of Edirne. The great architect Sinan built it in 1560 and after staying years long in oblivion, it was restored in 1968 and reused as a Hotel. Mimar Koca Sinan designed The Rüstem Pasha Caravanserai sited on the main land route between Europe and Asia. The Caravanserai's building was designed to surround the great rectangular courtyard with its marble basin in the centre as it is shown in Restoration and Adaptive reuse.

\subsubsection{Restoration and Adaptive reuse}

It was restored and converted into a 150-room hotel in 1972. Although the restoration itself represents a high standard of conception and performance, the hotel conversion proved impractical [13]. The jury commended the restoration of an important monument in spite

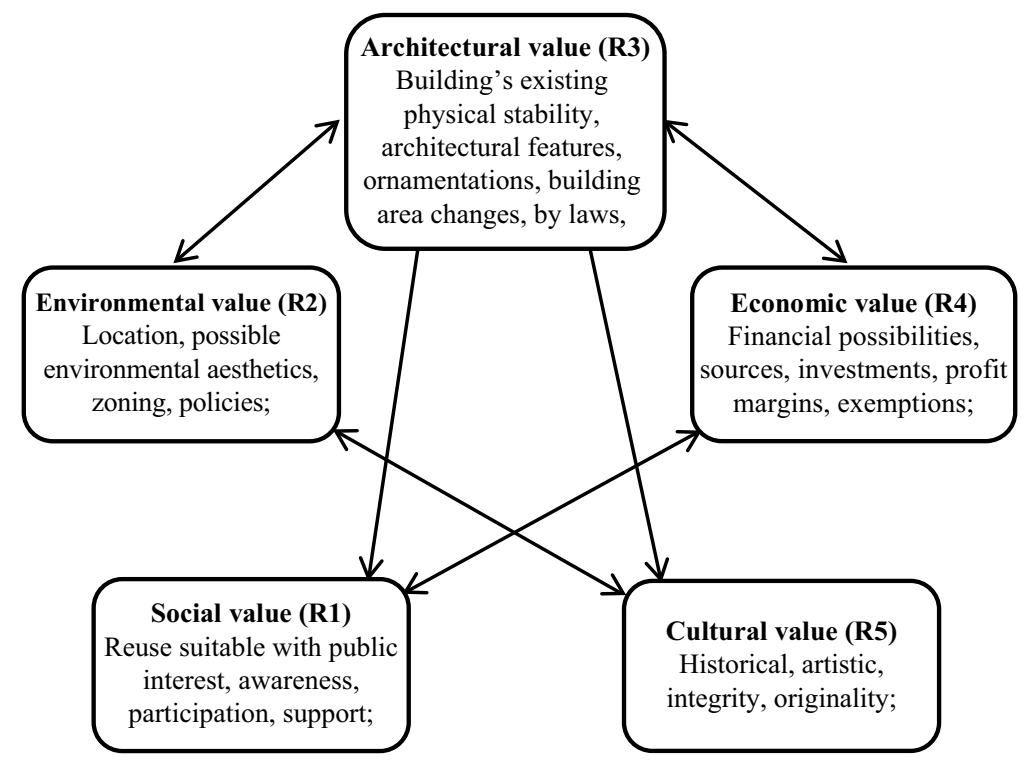

Figure 2: Set of values taken as criteria in the decision-making of the historical buildings' adaptive reuse [14]. 


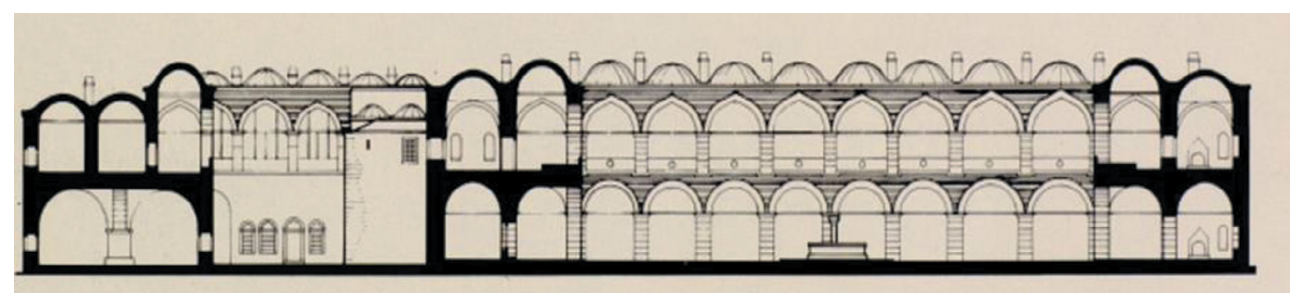

Figure 3: Section in the Rüstem Pasa Caravanserai, Edirne [15].
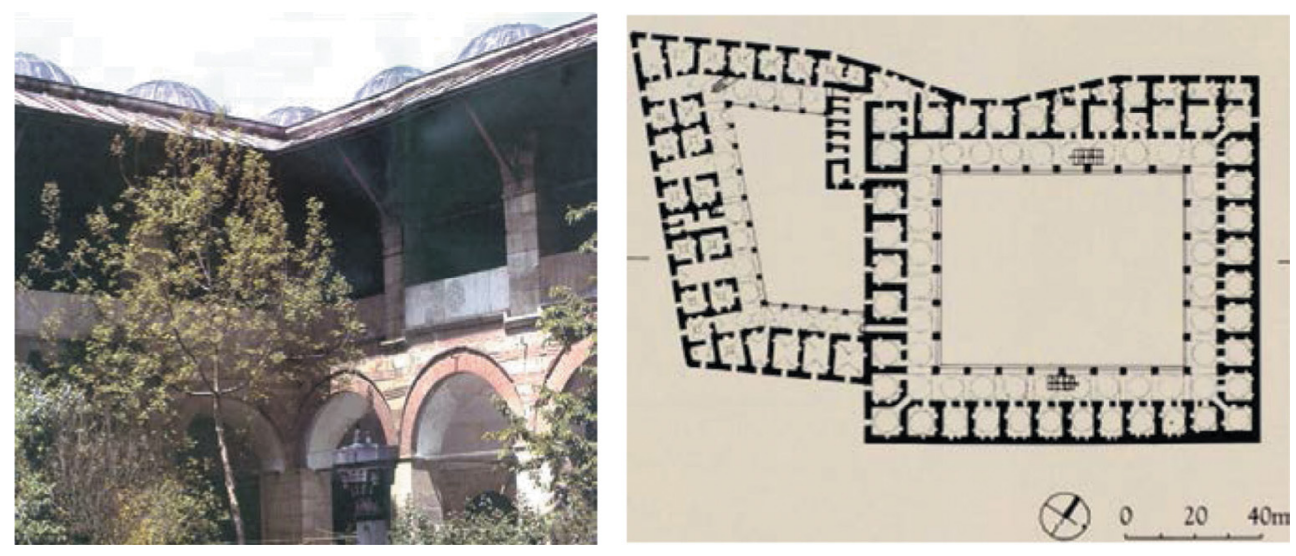

Figure 4: The inner courtyard has been transformed into garden for the new hotel [16].

of the failure of its re-use. However, the reuse of the ground floor was successful, where a restaurant for 136 people, cafeteria and a bar that can serve 75 people with separate entrances from the street were designed for the ground level in the small court (these rooms occupying the space formerly used as camel stables and an imaret), 21 Shops fronting the caravanserai were restored and once again leased to merchants [15] (Figs 3 and 4).

\subsubsection{Economic viability and social benefits}

- It generates income from activating the ground-floor shops and restaurant.

- Transforming the inner courtyard into garden accounts as an environmental benefit.

- The preservation of this major architectural monument is considered as a part of the national programmes of preservation.

- This project contributes in the revival of the cultural identity of the society.

\subsection{Khan Al-Wakalah, Nablus, Palestine}

\subsubsection{Brief description}

Khan Al-Wakalah building in Nablus is one of the model Ottoman caravansaries in Palestine. The architectural characteristics of the Khan Al-Wakalah match the general standards of Islamic khans, which were built inside cities, as it does not contain defence walls or other 
services that used to be found in caravanserais built outside cities. However, some of its components have distinctive shapes, due to the nature of the site where Khan Al-Wakalah was built, especially the shape of the courtyard which proves to be irregular, contrary to what is common in most other regular courtyards of Islamic khans [14].

\subsubsection{Restoration and adaptive reuse}

The restoration of the khan aims to revitalize the commercial and cultural life of Nablus. The renovation plan of the compound will house a small nine-room inn, a tourist centre and agencies to help visitors and several shops to sell traditional handicrafts such as the famous olive oil soap and traditional embroidery. A two-floor restaurant was established, and the old courtyard, where mules and camels used to be tethered overnight for hundreds of years, is now a venue for public events. The project also aimed at enhancing public awareness towards the protection and conservation of cultural heritage in Palestine by organizing several activities such as public lectures and site visits [17] (Fig. 5).

\subsubsection{Economic viability and social benefits}

- Adaptive reuse, which is a rehabilitation process, creates short-term job opportunities for locals during restoration. Labour regains lost traditional building and restoration skills.

- Heritage drives local communities with a powerful reason to look after their local environment and lead more sustainable lifestyles.

- The adaptation and rehabilitation process supports the use of historic buildings and links younger generation with their ancestors' living spaces, and interprets restored spaces by a contemporary meaning.

- Benefits include lower construction cost, lower land acquisition cost and less construction time depending on the extent of the work done.

- It conserves cultural identity which reinforces social coherence.

- It positively affects the surrounding in terms of encouraging upgrading the surrounding structures.

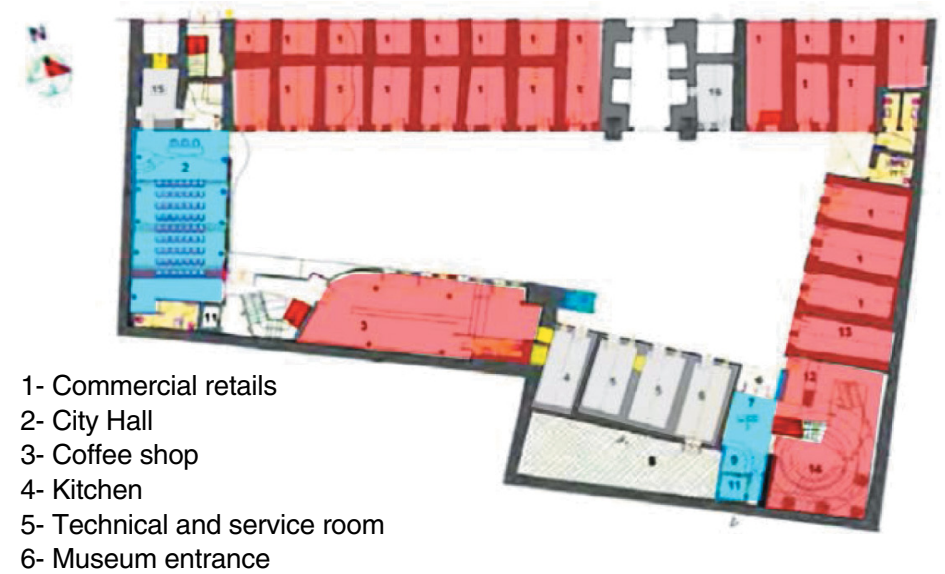

Ground-floor plan

Figure 5: Ground floor of the khan [14]. 


\subsection{Shah Abbas Hotel (Madarshah Caravanserai), Isfahan, Iran}

\subsubsection{Brief description}

Shah Abbas I of Persia established a comprehensive system of caravanserais all across his empire and throughout the Islamic world, providing hospitality and care for travellers, both pilgrims and strangers [18]. This example is the most famous caravanserai in Isfahan which is the Madarshah Caravanserai that was built in the 17th century in Chaharbagh Street; it is located in Isfahan Bazaar and reused as a modern hotel. The Caravanserais in the Isfahan Bazaar are the economic complexes with stores and places for (residing) housing merchants.

\subsubsection{Restoration and adaptive reuse}

The complex system of finances, grants and taxes that sustained the caravanserai and bazaar was a seminal act of financial engineering. It cross-subsidized the public functions of the college and mosque from the monetary income generated by the inn and shops [19]. The caravanserai was restored in 1951 by Andre Godard. It has been renovated, converted and expanded to contain a 216-room hotel with modern conveniences. A commercial complex has been built opposite the hotel housing shops. It is linked to the hotel by a public plaza (Fig. 6).

\subsubsection{Economic viability and social benefits}

- It generates income from accommodation service, restaurants and shops.

- It extends the life of the buildings.

- It creates job opportunities first in maintenance field and for all the workers who assure the functioning of the building as a hotel.

- Reuse building ameliorates the concept of the liveable historic world cities which attract investment.

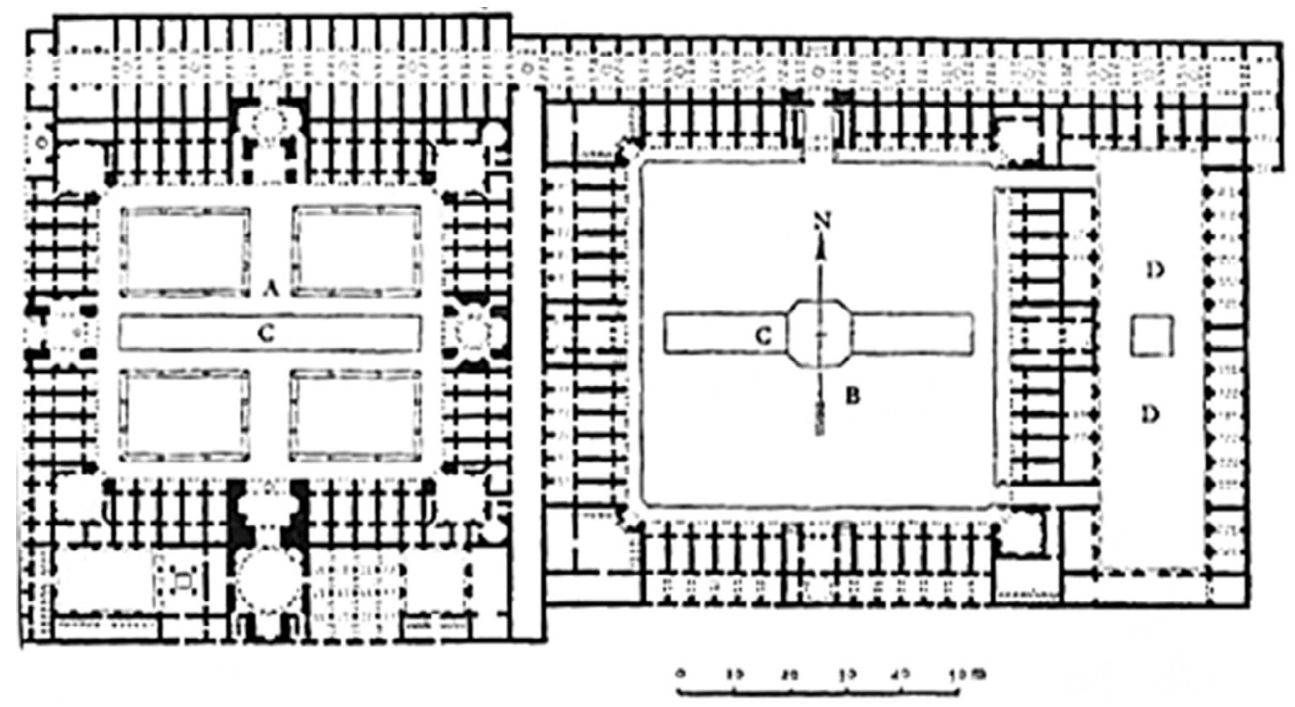

Figure 6: Plan of the Madrasa of Shah Sultan Husain at Isfahan: A - Madrasa. B Caravanserai. C - Ornamental canal. D - Stables [19]. 


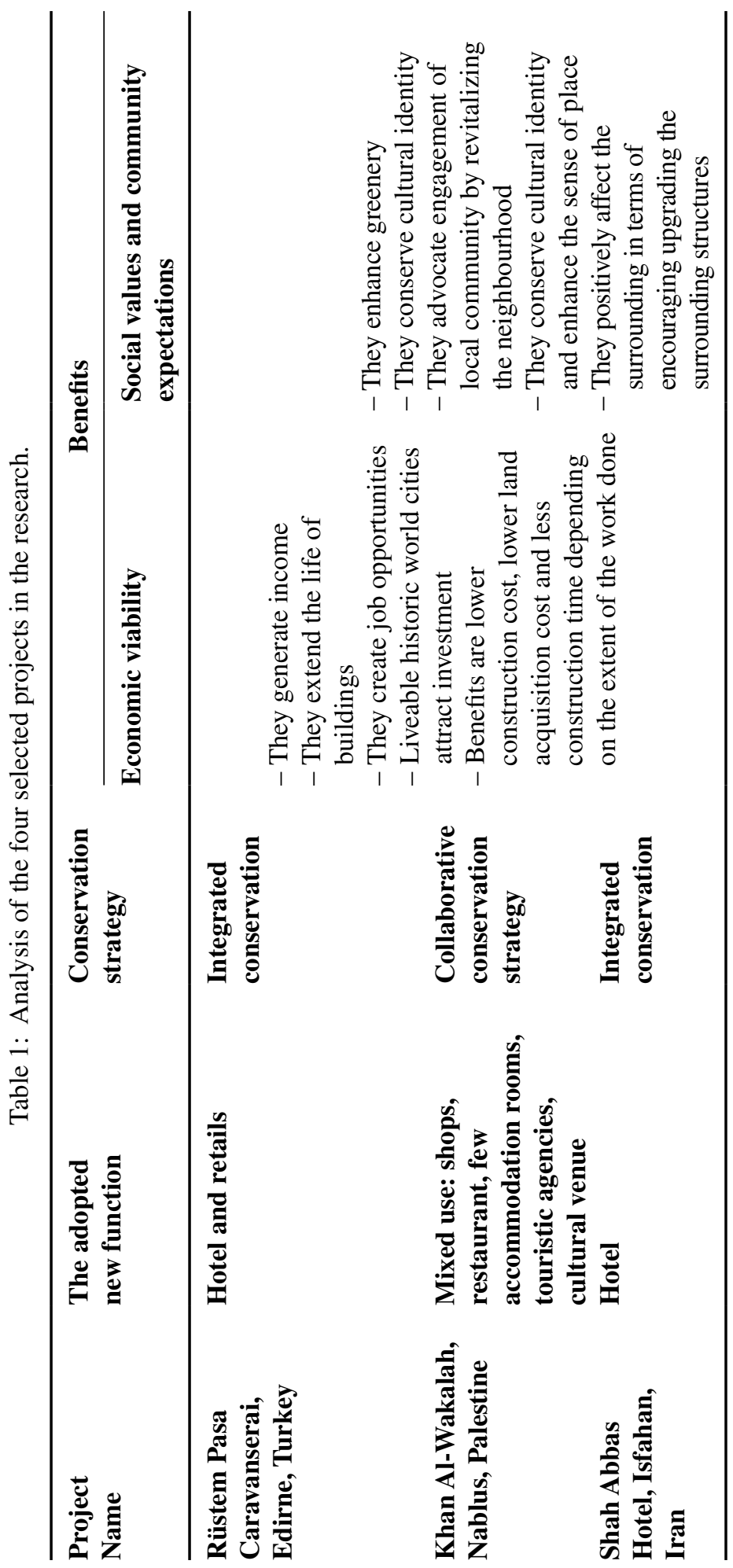


- Benefits include lower construction cost, lower land acquisition cost and less construction time depending on the extent of the work done.

- It conserves cultural identity which reinforces social coherence.

- It positively affects the surrounding in terms of encouraging upgrading the surrounding structures.

\section{EXAMPLE ANALYSIS AND DISCUSSION}

Table 1 summarizes the adaptive reuse of each example in this research. They represent successful adaptive reuse project, and they have common benefits as economic viability and community expectations.

From the case study analysis, we conducted the following points:

- Assisting and engaging local governments, non-governmental organizations, academic institutions and local community in the process of adaptive reuse of historic buildings.

- When setting goals of conservation management of the caravanserai, the decision makers should protect the cultural context within social fabric by preventing museumification and touristic priority.

- Establish sustainable conservation: because of the importance of the mixed-use city, there is no sustainability without integrating the old city to be a live city by its community, economic activities, cultural activities, as well as being friendly to the environment.

- From a conservationist perspective, the restoration followed by adaptation of the historic building should be authentic without harming the original features of the buildings.

- Since the image of the old city is not only shaped by the heritage buildings, but also by the livability of its community, a sustainable conservation of any heritage building should address the enhancement of young generation. relation with their cultural heritage.

\section{CONCLUSION}

Adaptive reuse enhances the longer-term usefulness of a building and is therefore a more sustainable option than demolition and rebuilding. The benefits from adaptive reuse include:

- Social Values and Community Expectations: It is important to have a community consultation and engagement to the ongoing effective adaptive reuse of historic buildings, particularly at old city proximity.

- Economic Viability: Disused historic buildings can have a negative socioeconomic impact on surrounding areas. In contrast, adaptive reuse of historic buildings can have a significant positive impact on the economic situation of the old city. These economic benefits are achieved through adaptive reuse in many ways as follow [7]:

- Extending the useful life of a buildings;

- Retaining the identity and cultural image of the old city;

- Creating proportionately more jobs than new construction;

- Enhancing the amenity of World Heritage old cities, which attracts people and investment.

- Environmental Sustainability: Retaining existing built fabric provides a number of environmental benefits, include reduced demolition waste, reduced resource consumption compared to a demolish-and-rebuild scenario, and the retention of the original building's embodied energy. 


\section{REFERENCES}

[1] Rodwell, D., Conservation and Sustainability in Historic Cities, Blackwell Publishing Ltd: Oxford, 2007.

[2] McCallum, Duncan. 2007. "Regeneration and the historic environment." In Understanding historic building conservation, ed. Michael Forsyth, 35-45. Oxford Blackwell Publishing

[3] Wilkinson, Sara J., Remøy, H., \& Langston, C., Sustainable Building Adaptation Innovations in Decision-Making, ed. RICS Research, Innovation in the Built Environment, Wiley Blackwell: Oxford, 2014.

[4] Fitch, James Marston. 1990. Historic Preservation, Curatorial Management of the Built World. Charlottesville and London: University Press of Virginia.

[5] Douglas, J., Building Adaptation, Butterworth-Heinemann, Elsevier: Oxford, 2006.

[6] Kincaid, D., Adapting Building for Changing Uses - Guidelines for Change of Use Refurbishment, Spon Press: London and New York, 2002.

[7] Ijla, Akram \& Broström, T., The sustainable viability of adaptive reuse of historic buildings: the experiences of two World Heritage old cities; Bethlehem in Palestine and Visby in Sweden. International Invention Journal of Arts and Social Sciences, 2(4), pp. 52-66, 2015.

[8] Gharipour, M., The culture and politics of commerce Bazaars in the Islamic world, The Bazaar in the Islamic City_Design, Culture, and History, ed. Mohammad Gharipour, The American University in Cairo Press: Cairo and New York, 2012.

[9] Williams, C., Islamic Monuments in Cairo: A Practical Guide, Cairo: American University in Cairo Press, 2008.

[10] Petersen, A., Dictionary of Islamic Architecture, London: Routledge, 1996.

[11] Saoud, R., Muslim Architecture under Ottoman Patronage, Foundation for Science, Technology, and Civilization: Manchester, 2004.

[12] Raymond, A., \& Gaston, W., Les Marchés du Caire: Traduction Annotée du Texte de Maqrizi, Institut français d'archéologie orientale du Caire: Cairo, 1979.

[13] Um, N., Spatial negotiations in a commercial city: The Red Sea Port of Mocha, Yemen, during the First Half of the 18th century. Journal of the Society of Architectural Historians, 62(2), pp. 178-193, 2003. DOI: 10.2307/3592476.

[14] Shehada, Ziad M. M., Bin Ahmad, Y., Yaacob, N. M., \& Keumala, N.I. M., Developing methodology for adaptive Re-use: Case study of heritage buildings in Palestine. ArchNet - International Journal of Architectural Research 9(2), pp. 216-229, 2015. DOI: 10.1108/20441261111171666.

[15] Çakirlar, Ertan, Rüstem Pasa Caravanserai, Edirne, Turkey. The Aga Khan Award for Architecture: Istanbul, 1972.

[16] Holod, Renata, \& Rastorfer, D., Rustem Pasha Caravanserai, Architecture and Community, eds. R. Holod and D. Rastorfer, Aperture: New York: 1983.

[17] Itma, Mohamad. 2011. Architectural characteristics of the Islamic Caravanserais case study: Khanalwakalah in the City of Nablus. An-Najah University Journal for Research-Natural Sciences, 25(1), pp. 123-142.

[18] O'Gorman, K. D., Historical giants: Forefathers of modern hospitality and tourism, Giants of Tourism, eds. R. Butler and R. Russell, CAB International: Oxfordshire, UK, pp. 3-17, 2010.

[19] Godard, André. 1965. The Art of Iran, ed. Michel Rogers. Frederick A. Praeger Publishers: New York. 